\title{
Analysis of HLA-G 5'URR regulatory polymorphisms in Slovak women with pre-eclampsia
}

\author{
Durmanova $\mathrm{V}^{1}$, Drobny $\mathrm{J}^{2}$, Dlhopolcek $\mathrm{J}^{2}$, Bucova $\mathrm{M}^{1}$ \\ Institute of Immunology, Faculty of Medicine, Comenius University in Bratislava, Bratislava, Slovakia. \\ vladimira.durmanova@fmed.uniba.sk
}

\section{ABSTRACT}

OBJECTIVES: The objective of this study was to identify the impact of the selected HLA-G gene polymorphisms in the $5^{\prime} U R R$ region on the risk to develop pre-eclampsia.

BACKGROUND: Pre-eclampsia (PE) is a serious multisystem disorder that affects women during pregnancy. Despite many research studies, the pathology of $P E$ is not fully understood. Human leukocyte antigen $G$ (HLA-G) belongs to the molecules that induce immune tolerance at the fetal-maternal interface. HLA-G expression was found to be impaired in the women suffering from PE suggesting its involvement in the development of PE.

METHODS: 116 women with pre-eclampsia and 130 women with normotensive pregnancy were included in the study. The 16 gene polymorphisms in the HLA-G 5'URR region (promoter) affecting HLA-G expression were typed by direct sequencing.

RESULTS: The -201AA genotypes in recessive model were significantly more frequent in women with preeclampsia than in the controls $(p=0.047)$. Furthermore, the analysis of HLA-G 5'URR variants with clinical findings of PE showed a significant association of the -533delA-/+ genotype with a higher mean level of diastolic blood pressure $(p=0.02)$.

CONCLUSION: Our results suggest a genetic association of selected HLA-G 5'URR variants with a risk of developing pre-eclampsia and possible contribution of HLA-G to disease pathology (Tab. 4, Ref. 51). Text in PDF www.elis.sk

KEY WORDS: HLA-G, pre-eclampsia, gene polymorphism, sequencing, diagnostics.

\section{Introduction}

Pre-eclampsia (PE) is a serious multisystem disorder observed in approximately 2 to $8 \%$ of all pregnancies. It accounts for the major cause of maternal morbidity and mortality worldwide (1). It is clinically characterized by hypertension (systolic and diastolic blood pressure of $\geq 140 / 90 \mathrm{~mm} \mathrm{Hg}$ ) and proteinuria (protein excretion of $\geq 300 \mathrm{mg}$ in a 24 hours urine collection) after 20 weeks of gestational age. The symptoms vary from mild to severe forms including the end organ damage such as HELLP (Hemolysis, Elevated liver enzymes and Low platelets) syndrome. Severe maternal complications may occur including: seizures, stroke, and liver and renal failure due to an acute tubular necrosis. Fetal complications include prematurity and low birth weight (2). Despite its clinical relevance and frequency, the etiology and pathogenic mechanisms

${ }^{1}$ Institute of Immunology, Faculty of Medicine, Comenius University in Bratislava, Bratislava, Slovakia, and ${ }^{2}$ Department of Obstetrics and Gynecology, Faculty of Medicine, University Hospital Bratislava, Comenius University in Bratislava, Bratislava, Slovakia

Address for correspondence: V. Durmanova, $\mathrm{PhD}$, Assoc Prof, Institute of Immunology, Faculty of Medicine, Comenius University in Bratislava, Odborarske namestie 14, SK-811 08 Bratislava, Slovakia.

Phone: +421.2 .90119887$
Tab. 1. Clinical characteristics of women with $P E(n=116)$.

\begin{tabular}{|c|c|}
\hline Parameter & Mean \pm SD/Number \\
\hline Age (years) & $32.00 \pm 5.16$ \\
\hline Onset of PE* & Early -31 , Late -85 \\
\hline Disease severity $* *$ & $\begin{array}{c}\text { Mild }-27 \\
\text { Moderate }-54 \\
\text { Severe }-35\end{array}$ \\
\hline Edema (yes/no) & $88 / 28$ \\
\hline Primiparous women (yes/no) & $69 / 47$ \\
\hline Preterm birth (yes/no) & $26 / 90$ \\
\hline The highest systolic $\mathrm{BP}(\mathrm{mmHg})$ & $154.00 \pm 15.88$ \\
\hline The highest diastolic $\mathrm{BP}(\mathrm{mmHg})$ & $98.53 \pm 8.96$ \\
\hline Leukocytes (x109/L) & $10.55 \pm 2.65$ \\
\hline Thrombocytes (x109/L) & $215.89 \pm 75.24$ \\
\hline Serum creatinine $(\mu \mathrm{mol} / \mathrm{L})$ & $59.47 \pm 12.88$ \\
\hline Uric acid $(\mu \mathrm{mol} / \mathrm{L})$ & $317.86 \pm 73.21$ \\
\hline ALT $(\mu \mathrm{kat} / \mathrm{L})$ & $0.43 \pm 0.61$ \\
\hline $\mathrm{AST}(\mu \mathrm{kat} / \mathrm{L})$ & $0.49 \pm 0.34$ \\
\hline Total serum proteins $(\mathrm{g} / \mathrm{L})$ & $58.85 \pm 6.63$ \\
\hline 14bp Ins positivity (yes/no) & $78 / 38$ \\
\hline \multicolumn{2}{|c|}{$\begin{array}{l}\text { BP - blood pressure, PE - pre-eclampsia, SD - standard deviation, *Early onset: } \\
\text { prior to } 37 \text { th week of gestation, Late onset: after } 37 \text { th week of gestation, **Mild: } \\
\text { BP is } 140 \text { to } 149 \mathrm{mmHg} \text { systolic and/ or } 90 \text { to } 99 \mathrm{mmHg} \text { diastolic, Moderate: BP is } \\
150 \text { to } 159 \mathrm{mmHg} \text { systolic and/ or } 100 \text { to } 109 \mathrm{mmHg} \text { diastolic, Severe: BP is } \geq 160 \\
\mathrm{mmHg} \text { systolic and/or } \geq 110 \mathrm{mmHg} \text { diastolic }\end{array}$} \\
\hline
\end{tabular}




\section{3-860}

Tab. 2. HLA-G 5'URR allele and genotype frequencies in patients with PE and controls.

\begin{tabular}{|c|c|c|c|c|c|c|}
\hline \multirow{2}{*}{$\begin{array}{l}\text { Allele/ } \\
\text { genotype }\end{array}$} & \multirow{2}{*}{$\begin{array}{c}P E \\
(n=116)\end{array}$} & \multirow{2}{*}{$\begin{array}{l}\text { Control group } \\
\quad(n=130)\end{array}$} & \multicolumn{2}{|c|}{ Univariate analysis } & \multicolumn{2}{|c|}{ Multivariate analysis } \\
\hline & & & $\mathrm{p}$ & OR $(95 \% \mathrm{CI})$ & $\mathrm{p}$ & OR $(95 \% \mathrm{CI})$ \\
\hline \multicolumn{7}{|c|}{ Haploblock -762C/T, -716T/G, -689A/G, -666G/T, -633G/A } \\
\hline$-762 \mathrm{C}$ & $109(46.98 \%)$ & $141(54.23 \%)$ & & & & \\
\hline$-762 \mathrm{~T}$ & $123(53.02 \%)$ & $119(45.77 \%)$ & 0.13 & $1.34(0.94-1.91)$ & - & - \\
\hline $\mathrm{CC}$ & $28(24.14 \%)$ & $39(30.00 \%)$ & & 1.00 & & 1.00 \\
\hline $\mathrm{CT}$ & $53(45.69 \%)$ & $63(48.46 \%)$ & 0.26 & $1.17(0.64-2.15)$ & 0.24 & $1.78(0.61-5.20)$ \\
\hline $\mathrm{TT}$ & $35(30.17 \%)$ & $28(21.54 \%)$ & & $1.74(0.87-3.49)$ & & $2.70(0.81-9.01)$ \\
\hline $\operatorname{HWE}\left(\chi^{2} / \mathrm{P}\right)$ & $0.80 / 0.37$ & $0.07 / 0.79$ & & & & \\
\hline \multicolumn{7}{|l|}{$-725 \mathrm{C} / \mathrm{G} / \mathrm{T}$} \\
\hline $\mathrm{C}$ & $196(84.48 \%)$ & $218(83.85 \%)$ & & & & \\
\hline G & $30(12.93 \%)$ & $35(13.46 \%)$ & & & - & - \\
\hline $\mathrm{T}$ & $6(2.59 \%)$ & $7(2.69 \%)$ & 0.94 & $0.96(0.32-2.90)$ & - & - \\
\hline $\mathrm{CC}+\mathrm{CG}+\mathrm{GG}$ & $110(94.83 \%)$ & $123(94.62 \%)$ & & 1.00 & - & - \\
\hline $\mathrm{CT}+\mathrm{GT}+\mathrm{TT}$ & $6(5.17 \%)$ & $7(5.38 \%)$ & 0.94 & $0.96(0.31-2.94)$ & - & - \\
\hline \multicolumn{7}{|l|}{$-646 \mathrm{~A} / \mathrm{G}$} \\
\hline $\mathrm{A}$ & $228(98.28 \%)$ & $257(98.85 \%)$ & & & & \\
\hline G & $4(1.72 \%)$ & $3(1.15 \%)$ & 0.88 & $1.50(0.33-6.79)$ & - & - \\
\hline AA & $112(96.55 \%)$ & $127(97.69 \%)$ & & 1.00 & & 1.00 \\
\hline $\mathrm{AG}$ & $4(3.45 \%)$ & $3(2.31 \%)$ & 0.59 & $1.51(0.33-6.90)$ & 0.32 & $2.30(0.44-11.93)$ \\
\hline GG & $0(0.00 \%)$ & $0(0.00 \%)$ & & - & & - \\
\hline $\operatorname{HWE}\left(\chi^{2} / \mathrm{P}\right)$ & $0.04 / 0.85$ & $0.02 / 0.89$ & & & & \\
\hline \multicolumn{7}{|l|}{$-540 \mathrm{insG}$} \\
\hline insG- & $231(99.57 \%)$ & $256(98.46 \%)$ & & & & \\
\hline insG+ & $1(0.43)$ & $4(1.54 \%)$ & 0.44 & $0.28(0.03-2.50)$ & - & - \\
\hline insG-/- & $115(99.14 \%)$ & $126(96.92 \%)$ & & 1.00 & & 1.00 \\
\hline insG-/+ & $1(0.86 \%)$ & $4(3.08 \%)$ & 0.20 & $0.27(0.03-2.48)$ & 0.37 & $0.37(0.04-3.69)$ \\
\hline insG $+/+$ & $0(0.00 \%)$ & $0(0.00 \%)$ & & - & & - \\
\hline $\operatorname{HWE}\left(\chi^{2} / \mathrm{P}\right)$ & $0.002 / 0.96$ & $0.03 / 0.86$ & & & & \\
\hline $\operatorname{del} \mathrm{A}+$ & $2(0.86 \%)$ & $4(1.54 \%)$ & 0.79 & $0.56(0.10-3.07)$ & - & - \\
\hline delA-/- & $114(98.28 \%)$ & $126(96.92 \%)$ & & 1.00 & & 1.00 \\
\hline $\operatorname{delA}-/+$ & $2(1.72 \%)$ & $4(3.08 \%)$ & 0.49 & $0.55(0.10-3.07)$ & 0.63 & $0.64(0.10-4.03)$ \\
\hline $\operatorname{del} \mathrm{A}+/+$ & $0(0.00 \%)$ & $0(0.00 \%)$ & & - & & - \\
\hline $\operatorname{HWE}\left(\chi^{2} / \mathrm{P}\right)$ & $0.009 / 0.93$ & $0.03 / 0.86$ & & & & \\
\hline \multicolumn{7}{|l|}{$-509 \mathrm{C} / \mathrm{G}$} \\
\hline $\mathrm{C}$ & $229(98.71 \%)$ & $256(98.46 \%)$ & & & & \\
\hline G & $3(1.29 \%)$ & $4(1.54 \%)$ & 0.82 & $0.84(0.19-3.79)$ & - & - \\
\hline $\mathrm{CC}$ & $113(97.41 \%)$ & $126(96.92 \%)$ & & 1.00 & & 1.00 \\
\hline $\mathrm{CG}$ & $3(2.59 \%)$ & $4(3.08 \%)$ & 0.82 & $0.84(0.18-3.82)$ & 0.98 & $1.02(0.19-5.42)$ \\
\hline GG & $0(0.00 \%)$ & $0(0.00 \%)$ & & - & & - \\
\hline $\operatorname{HWE}\left(\chi^{2} / \mathrm{P}\right)$ & $0.02 / 0.89$ & $0.03 / 0.86$ & & & & \\
\hline \multicolumn{7}{|l|}{$-486 \mathrm{~A} / \mathrm{C}$} \\
\hline $\mathrm{A}$ & $108(46.55 \%)$ & $140(53.85 \%)$ & & & & \\
\hline $\mathrm{C}$ & $124(53.45 \%)$ & $120(46.15 \%)$ & 0.13 & $1.34(0.94-1.91)$ & - & - \\
\hline AA & $28(24.14 \%)$ & $39(30.00 \%)$ & & 1.00 & & 1.00 \\
\hline $\mathrm{AC}$ & $52(44.83 \%)$ & $62(47.69 \%)$ & 0.27 & $1.17(0.64-2.15)$ & 0.23 & $1.77(0.61-5.19)$ \\
\hline $\mathrm{CC}$ & $36(31.03 \%)$ & $29(22.31 \%)$ & & $1.73(0.87-3.44)$ & & $2.73(0.82-9.08)$ \\
\hline $\operatorname{HWE}\left(\chi^{2} / \mathrm{P}\right)$ & $1.14 / 0.29$ & $0.21 / 0.64$ & & & & \\
\hline \multicolumn{7}{|l|}{$-477 \mathrm{G} / \mathrm{C}$} \\
\hline $\mathrm{C}$ & $106(45.69 \%)$ & $135(51.92 \%)$ & & & & \\
\hline $\mathrm{G}$ & $126(54.31 \%)$ & $125(48.08 \%)$ & 0.20 & $1.28(0.90-1.83)$ & - & - \\
\hline GG & $38(32.76 \%)$ & $34(26.15 \%)$ & & 1.00 & & 1.00 \\
\hline GC & $50(43.10 \%)$ & $57(43.85 \%)$ & 0.43 & $0.78(0.43-1.43)$ & 0.32 & $0.74(0.36-1.53)$ \\
\hline $\mathrm{CC}$ & $28(24.14 \%)$ & $39(30.00 \%)$ & & $0.64(0.33-1.26)$ & & $0.41(0.12-1.34)$ \\
\hline $\operatorname{HWE}\left(\chi^{2} / \mathrm{P}\right)$ & $2.01 / 0.16$ & $1.93 / 0.16$ & & & & \\
\hline
\end{tabular}




\begin{tabular}{|c|c|c|c|c|c|c|}
\hline \multirow{2}{*}{$\begin{array}{l}\begin{array}{l}\text { Allele/ } \\
\text { genotype }\end{array} \\
\end{array}$} & \multirow{2}{*}{$\begin{array}{c}\text { PE } \\
(n=116)\end{array}$} & \multirow{2}{*}{$\begin{array}{c}\text { Control group } \\
(n=130)\end{array}$} & \multicolumn{2}{|c|}{ Univariate analysis } & \multicolumn{2}{|c|}{ Multivariate analysis } \\
\hline & & & $\mathrm{p}$ & OR $(95 \% \mathrm{CI})$ & $\mathrm{p}$ & OR $(95 \% \mathrm{CI})$ \\
\hline \multicolumn{7}{|l|}{$-400 \mathrm{G} / \mathrm{A}$} \\
\hline G & $228(98.28 \%)$ & $255(98.08 \%)$ & & & & \\
\hline A & $4(1.72 \%)$ & $5(1.92 \%)$ & 0.87 & $0.89(0.24-3.37)$ & - & - \\
\hline GG & $112(96.55 \%)$ & $125(96.15 \%)$ & & 1.00 & & 1.00 \\
\hline GA & $4(3.45 \%)$ & $5(3.85 \%)$ & 0.87 & $0.89(0.23-3.41)$ & 0.82 & $1.19(0.28-5.12)$ \\
\hline AA & $0(0.00 \%)$ & $0(0.00 \%)$ & & - & & - \\
\hline HWE $\left(\chi^{2} / \mathrm{P}\right)$ & $0.04 / 0.85$ & $0.05 / 0.82$ & & & & \\
\hline \multicolumn{7}{|l|}{$-391 \mathrm{G} / \mathrm{A}$} \\
\hline G & $228(98.28 \%)$ & $254(97.69 \%)$ & & & & \\
\hline $\mathrm{A}$ & $4(1.72 \%)$ & $6(2.31 \%)$ & 0.89 & $0.74(0.21-2.67)$ & - & - \\
\hline GG & $112(96.55 \%)$ & $124(95.38 \%)$ & & 1.00 & & 1.00 \\
\hline GA & $4(3.45 \%)$ & $6(4.62 \%)$ & 0.64 & $0.74(0.20-2.68)$ & 0.82 & $1.19(0.28-5.11)$ \\
\hline AA & $0(0.00 \%)$ & $0(0.00 \%)$ & & - & & - \\
\hline $\operatorname{HWE}\left(\chi^{2} / \mathrm{P}\right)$ & $0.04 / 0.85$ & $0.07 / 0.79$ & & & & \\
\hline \multicolumn{7}{|l|}{$-369 \mathrm{~A} / \mathrm{C}$} \\
\hline $\mathrm{C}$ & $105(45.26 \%)$ & $135(51.92 \%)$ & & & & \\
\hline $\mathrm{A}$ & $127(54.74 \%)$ & $125(48.08 \%)$ & 0.17 & $1.30(0.92-1.86)$ & - & - \\
\hline AA & $38(32.76 \%)$ & $34(26.15 \%)$ & & 1.00 & & 1.00 \\
\hline $\mathrm{AC}$ & $51(43.97 \%)$ & $57(43.85 \%)$ & 0.38 & $0.80(0.44-1.45)$ & 0.18 & $0.76(0.37-1.56)$ \\
\hline $\mathrm{CC}$ & $27(23.27 \%)$ & $39(30.00 \%)$ & & $0.62(0.32-1.22)$ & & $0.32(0.09-1.11)$ \\
\hline $\operatorname{HWE}\left(\chi^{2} / \mathrm{P}\right)$ & $1.47 / 0.22$ & $1.93 / 0.16$ & & & & \\
\hline \multicolumn{7}{|l|}{$-201 \mathrm{G} / \mathrm{A}$} \\
\hline $\mathrm{G}$ & $106(45.69 \%)$ & $141(54.23 \%)$ & & & & \\
\hline $\mathrm{A}$ & $126(54.31 \%)$ & $119(45.77 \%)$ & 0.07 & $1.41(0.99-2.01)$ & - & - \\
\hline GG & $28(24.14 \%)$ & $39(30.00 \%)$ & & 1.00 & & 1.00 \\
\hline GA & $50(43.10 \%)$ & $63(48.46 \%)$ & 0.13 & $1.11(0.60-2.04)$ & 0.11 & $1.70(0.58-4.99)$ \\
\hline AA & $38(32.76 \%)$ & $28(21.54 \%)$ & & $1.89(0.95-3.76)$ & & $3.15(0.94-10.62)$ \\
\hline GG & $28(24.14 \%)$ & $39(30.00 \%)$ & & 1.00 & & 1.00 \\
\hline $\mathrm{GA}+\mathrm{AA}$ & $88(75.86 \%)$ & $91(70.00 \%)$ & 0.30 & $1.35(0.76-2.37)$ & 0.2 & $1.97(0.69-5.62)$ \\
\hline $\mathrm{GG}+\mathrm{GA}$ & $78(67.24 \%)$ & $102(78.46 \%)$ & & 1.00 & & 1.00 \\
\hline $\mathrm{AA}$ & $38(32.76 \%)$ & $28(21.54 \%)$ & 0.047 & $1.77(1.00-3.14)$ & 0.07 & $1.97(0.95-4.07)$ \\
\hline $\operatorname{HWE}\left(\chi^{2} / \mathrm{P}\right)$ & $2.01 / 0.16$ & $0.07 / 0.79$ & & & & \\
\hline
\end{tabular}

Allele and genotype frequencies are presented as absolute numbers with percentages in parentheses. Univariate analysis is based on $\chi^{2}$ test. Multivariate analysis is adjusted by age and 14bp Ins positivity. $\mathrm{p}<0.05$ was considered as statistically significant. CI - confidence interval, HWE - Hardy-Weinberg equilibrium, OR - odds ratio, $\mathrm{n}-\mathrm{number}$

of PE remain still unclear. One cause may originate in an insufficiently developed placenta, referred to as poor placentation. It is characterized by impaired re-modelling of spiral arteries of the uterus caused by an imbalance of circulating angiogenic factors (3). Other key mechanisms leading to PE besides poor placentation are inflammation and aberrant immune interactions at the fetal-maternal interface (4).

Suitable biomarkers that could predict the risk of PE are still subject of investigation $(5,6)$. One of the candidate molecules that plays a beneficial role in the pregnancy is the human leukocyte antigen G (HLA-G). HLA-G belongs to the non-classical HLA-class I molecules and is involved in the extravillous suppression of immune response. It is mainly expressed in extra villous cytotrophoblast that helps to protect the fetus from maternal immune response (7). There are four membrane- bound isoforms HLA-G1, -G2, -G3, and -G4, and three soluble isoforms HLA-G5, -G6, and -G7 (8).

HLA-G mediates an inhibition of cytotoxic activity of uterine and peripheral blood natural killers $(\mathrm{NK})$ cells and $\mathrm{CD} 8^{+} \mathrm{T}$ cells, the alloproliferative response of $\mathrm{CD} 4^{+} \mathrm{T}$ cells, inhibition of dendritic cell maturation and the differentiation of $\mathrm{CD} 4^{+} \mathrm{T}$-cells into regulatory T cells (9). Immunosuppressive activity of the HLA-G molecule is mediated mainly through its interaction with inhibitory receptors of immune cells, i.e. ILT-2 receptor present on B cells, antigen-presenting cells (APC) and some T, and NK cells, ILT-4 receptor present on APC and KIR2DL4 expressed by NK and some T cells (10). HLA-G can also induce the generation of immunosuppressive HLA-G ${ }^{+}$APCs, such as DC-10 and HLA-G ${ }^{+}$ macrophages via trogocytosis (11). Finally, sHLA-G interacts with $\mathrm{CD} 8$ and triggers apoptosis of $\mathrm{CD} 8^{+}$cells by Fas/Fas-ligand interaction (12). In addition to its immunosuppressive activity, HLA-G is involved in ensuring an successful invasion of placental tissues into the maternal decidua (13).

The HLA-G gene is 4170 bp long and consists of 8 exons. It is characterized by low polymorphism, namely 82 HLA-G alleles, 22 HLA-G proteins, and 4 null alleles have been identified to date (IMGT/HLA release 3.42.0, September 2020). The most polymorphic sites that influence HLA-G expression were identified in two noncoding regions: the upstream regulatory region ( $\left.5^{\prime} \mathrm{URR}\right)$ and untranslated region ( $3^{\prime} \mathrm{UTR}$ ). In the $3^{\prime} \mathrm{UTR}$ region, a $14 \mathrm{bp}$ insertion polymorphism ( $5^{\prime}$-ATTTGTTCATGCCT-3') has been described, which affects the stability of mRNA causing decreased production of most membrane and soluble isoforms (14). HLA-G 
853-860

5'URR region consists of the $1.4 \mathrm{~kb}$ upstream the ATG and shows at least 35 SNPs defining 68 haplotypes, of which 9-10 have been frequently observed in human populations (15). Several enhancer and suppressor elements have been described within the HLA-G 5'URR region to regulate HLA-G expression (16-18).

In women suffering from PE, the decreased HLA-G level was determined (19-23). As the expression of soluble HLA-G may be influenced by the above-mentioned HLA-G gene polymorphisms, the possible association between these variants and the risk of PE has been investigated. The most studies analyzed the impact of $14 \mathrm{bp} \mathrm{Ins/Del} \mathrm{polymorphism} \mathrm{on} \mathrm{the} \mathrm{risk} \mathrm{of} \mathrm{PE} \mathrm{development}$ (23-31). However, no study evaluated the association between HLA-G 5'URR polymorphisms and the risk of developing PE so far. Thus, the aim of the study was to analyze the association between 16 polymorphic variants in HLA-G 5'URR region and clinical findings in women with PE.

\section{Materials and methods}

\section{Study subjects}

We investigated 116 women suffering from pre-eclampsia and 130 women with physiological pregnancies. PE was defined as the presence of blood pressure of at least $140 / 90 \mathrm{mmHg}$ with readings at least 6 hours apart and proteinuria $(300 \mathrm{mg} / 24 \mathrm{~h}$ or $\geq 30 \mathrm{mg} / \mathrm{dl}$ by urine analysis (32). The clinical characteristics of the women with $\mathrm{PE}$ are shown in the Table 1. The mean age of women with PE was $32.00 \pm 5.16$ years; the mean age of controls was $40.22 \pm 9.28$. All the study subjects provided a written informed consent for enrolling in the study and for personal data management. The study was approved by the Ethics Committee of the University Hospital Bratislava. All the investigations were carried out in accordance with the International Ethical Guidelines and the Declaration of Helsinki.

\section{Sequencing of the HLA-G 5'URR region}

Genomic DNA was isolated from EDTA-treated peripheral $\mathrm{PE}$ and control blood samples $(2 \mathrm{~mL})$ by a modified salting-out procedure (33). To quantify the amount and purity of DNA, the Nanodrop spectrophotometer was used (Thermo Fisher Scientific). HLA-G 5'URR region from $-828 \mathrm{bp}$ to $-5 \mathrm{bp}$ was amplified by forward primer 5'- CACGGAAACTTAGGGCTACGG-3 and reverse primer 5'- GCGTCTGGGGAGAATGAGTCC-3' as described by Catamo et al (34). A PCR reaction mixture with a total volume of $25 \mu \mathrm{L}$ contained $50 \mathrm{ng}$ of template DNA, $0.2 \mathrm{mM}$ of each dNTP (Thermo Fisher Scientific, USA), 1 U of Taq DNA polymerase (Thermo Fisher Scientific, USA), $1.5 \mathrm{mmol} \mathrm{MgCl}_{2}$ (Thermo Fisher Scientific, USA), and 10 pmol of each specific primer. The PCR conditions were $95^{\circ} \mathrm{C}$ for $3 \mathrm{~min}$, followed by 30 cycles (denaturation at $95^{\circ} \mathrm{C}$ for $1 \mathrm{~min}$, annealing at $65^{\circ} \mathrm{C}$ for $30 \mathrm{~s}$, and elongation at $72{ }^{\circ} \mathrm{C}$ for $1 \mathrm{~min}$ ) and final elongation at $72{ }^{\circ} \mathrm{C}$ for $10 \mathrm{~min}$. The PCR products were run in $1.0 \%$ agarose gel for $20 \mathrm{~min}$ and then visualized under UV light. Fragment size of 823 bp was confirmed using the 100 bp DNA ladder (Solis BioDyne, EU). For a direct sequence analysis, the PCR products were purified using an EXO SAP-IT kit according to the manufacturer's recommendations (USB, USA) and then sequenced (approxi- mately $100 \mathrm{ng}$ ) using BigDye Terminator v3.1 Cycle Sequencing Kit (Thermo Fisher Scientific, USA). The PCR products were sequenced individually on both strands using forward and reverse PCR primers. The sequencing reaction was run on a $3130 \mathrm{ABI}$ PRISM Genetic analyzer (Applied Biosystems) and the sequence data were analyzed by SeqScape software (Applied Biosystems) using the reference sequence reported on website http:// www.ebi. ac.uk/imgt/hla/align.html.

\section{Statistical analysis}

Allele and genotype frequencies were evaluated by a direct counting. Genotypes were tested for their fit to Hardy-Weinberg equilibrium using the chi-square test. Haplotype frequency estimation was defined using PHASE 2.1 software (35). Statistical significance of differences in allele, genotype and haplotype frequencies between the two studied groups (women with pre-eclampsia vs control group) was evaluated by the standard chi square test using the InStat statistical software (GraphPad Software, Inc., San Diego, USA). The $\mathrm{p}$ values, odds ratios (OR) and $95 \%$ confidence intervals $(95 \% \mathrm{CI})$ were calculated in co-dominant, dominant and recessive inheritance models. The multivariate logistic regression analysis adjusted for age and HLA-G +14 bp Ins positivity as possible influencing factors was performed by the SNPstats web software available at https://snapstat.net/snpstats/. Finally, linear regression analysis and Student t-test with Welch correction was used to investigate the correlation between HLA-G 5'URR polymorphisms and clinical variables as the onset of PE, the highest systolic blood pressure (BP), the highest diastolic BP, serum creatinine, uric acid and total serum proteins level. The $\mathrm{p}$ value of $<0.05$ was considered statistically significant.

\section{Results}

\section{Characteristics of the women with pre-eclampsia}

The clinical characteristics of the women with PE are shown in the Table 1. The mean age of women with PE was $32.00 \pm 5.16$ years. Out of 116 women with PE, 69 were primiparous. Early disease onset (before 37th week of gestation) was observed in 31 women. The mean gestation week at PE onset was $34.62 \pm 4.42$. Regarding the disease severity, mild PE $(\mathrm{BP} \leq 140 / 90 \mathrm{mmHg})$ was classified in 27 women, moderate PE (BP from 140/90 to 150/100 $\mathrm{mmHg})$ was classified in 54 women and severe $\mathrm{PE}(\mathrm{BP} \geq 160 / 110$ $\mathrm{mmHg}$ ) was observed in 35 women. The mean highest systolic blood pressure of the women with PE was $154.00 \pm 15.88 \mathrm{mmHg}$, the mean highest diastolic blood pressure was $98.53 \pm 8.96 \mathrm{mmHg}$. Oedemas were observed in 88 women suffering from PE.

HLA-G 5'URR allele and genotype frequencies among women with $P E$ and the control group

In 116 women with PE and 130 controls, 16 polymorphisms in the HLA-G 5'URR region have been analyzed: $-762 \mathrm{C} / \mathrm{T}$ (rs1632946), -725C/G/T (rs1233334), -716T/G (rs2249863), $-689 \mathrm{~A} / \mathrm{G}(\mathrm{rs} 2735022),-666 \mathrm{G} / \mathrm{T} \quad(\mathrm{rs} 35674592),-646 \mathrm{~A}>\mathrm{G}$ (rs17875391), -633G/A (rs1632944), -540insG (rs17875392), -533delA (rs370236002), -509C/G (rs17875393), -486A/C 
Tab. 3. HLA-G 5'URR haplotypes/3'UTR 14bp Ins/Del among women with pre-eclampsia and control group.

\begin{tabular}{lccc}
\hline Haplotypes & $\begin{array}{c}\text { Pre-eclampsia } \\
\text { 2N (\%) }\end{array}$ & $\begin{array}{c}\text { Control group } \\
\text { 2N }(\%)\end{array}$ & $\mathrm{p}$ \\
\hline 5'URR-1 (TCGGTAACCGGGAAIns) & $96(41.38 \%)$ & $94(36.15 \%)$ & 0.2732 \\
5'URR-2 (CCTAGAGCACGGCGDel) & $71(30.60 \%)$ & $96(36.92 \%)$ & 0.1668 \\
5'URR-3 (CGTAGAGCACGGCGDel) & $29(12.50 \%)$ & $36(13.85 \%)$ & 0.7590 \\
5'URR-4 (TCGGTAACCGGGAADel) & $27(11.64 \%)$ & $21(8.08 \%)$ & 0.2393 \\
5'URR-5 (CTTAGGGGAGAAAAIns) & $3(1.29 \%)$ & $0(0.00 \%)$ & 0.2080 \\
5'URR-6 (CCTAGAGdelACACGGCGDel) & $2(0.86 \%)$ & $1(0.39 \%)$ & 0.9211 \\
5'URR-7 (CTTAGAGinsGCACGGCGIns) & $1(0.43 \%)$ & $1(0.39 \%)$ & 0.9356 \\
5'URR-8 (CGTAGAGCCCGGCGDel) & $1(0.43 \%)$ & $0(0.00 \%)$ & 0.9545 \\
5'URR-9 (CTTAGGGCACAAAGIns) & $1(0.43 \%)$ & $0(0.00 \%)$ & 0.9545 \\
5'URR-10 (CTTAGAGCACGGCGIns) & $1(0.43 \%)$ & $0(0.00 \%)$ & 0.9545 \\
5'URR-11 (CCTAGAGCCGGGAAIns) & $0(0.00 \%)$ & $4(1.54 \%)$ & 0.1633 \\
5'URR-12 (TTGGTGAGAGAAAGIns) & $0(0.00 \%)$ & $3(1.15 \%)$ & 0.2887 \\
Others* & $0(0.00 \%)$ & 5 $(1.92 \%)$ & 0.0944 \\
\hline
\end{tabular}

Sample size: Pre-eclampsia $2 \mathrm{~N}=232$, Control group $2 \mathrm{~N}=260$. $\mathrm{p}$ values were calculated using $\chi^{2}$ test. $\mathrm{p}<0.01$ was considered as statistically significant. $\mathrm{n}$ - number, UTR - untranslated region, Ins - insertion, Del - deletion. *Group of all haplotypes with frequency lower than $1 \%$. Haplotype consensus sequences are represented by: $-762 \mathrm{C} / \mathrm{T},-725 \mathrm{C} / \mathrm{G} / \mathrm{T},-716 \mathrm{G} / \mathrm{T},-689 \mathrm{G} / \mathrm{A},-666 \mathrm{~T} / \mathrm{G},-646 \mathrm{~A} / \mathrm{G},-633 \mathrm{G} / \mathrm{A},-540 \mathrm{insG},-533 \mathrm{del} \mathrm{A},-509 \mathrm{C} / \mathrm{G},-486 \mathrm{C} / \mathrm{A}$, $-477 \mathrm{G} / \mathrm{C},-400 \mathrm{G} / \mathrm{A},-391 \mathrm{G} / \mathrm{A},-369 \mathrm{~A} / \mathrm{C},-201 \mathrm{~A} / \mathrm{G}, 14 \mathrm{bp}$ Ins/Del after adjustment for age and $+14 \mathrm{bp}$ Ins, no statistically significant differences in allele and genotypes frequencies between women with PE and the controls were observed ( $p$ $>0.05$ ) (Tab. 2).

The distribution of the HLA-G 5'URR haplotypes in women with PE and the control group was also performed (Tab. 3). Phase software estimated 10 HLA-G 5'URR haplotypes in women with PE and 12 HLAG 5'URR haplotypes in the control group. The HLA-G 5'URR-1 was the most frequent haplotype in women with PE, and HLA-G 5'URR-2 was the most frequent in the control group. No statistically significant differences in haplotype frequencies between PE patients and the controls were observed $(\mathrm{p}>0.05)$ (Tab. 3). (rs1736933), -477G/C (rs1736932), -400G/A(rs17875395), -391G/ A(rs17875396), -369A/C (rs1632943), -201G/A(rs1233333). Distribution of HLA-G $14 \mathrm{bp}$ insertion/deletion polymorphism in the HLA-G 3'UTR region was described previously (30). Allele and genotype frequencies of the HLA-G 5'URR gene polymorphisms observed in analyzed groups are shown in Table 2. Genotype frequencies fit the Hardy-Weinberg equilibrium in women with $\mathrm{PE}$ $(\chi 2=0.002-2.01, \mathrm{p}=0.16-0.96)$ as well as in the controls $(\chi 2=$ $0.02-1.93, \mathrm{p}=0.16-0.89)$. In the HLA-G 5'URR region, 5 SNPs, namely $-762 \mathrm{C} / \mathrm{T},-716 \mathrm{~T} / \mathrm{G},-689 \mathrm{~A} / \mathrm{G},-666 \mathrm{G} / \mathrm{T},-633 \mathrm{G} / \mathrm{A}$, were in strong linkage disequilibrium (LD) and constituted a haploblock (D'> 0.99). The analysis of 16 HLA-G 5'URR variants revealed that $-201 \mathrm{AA}$ carriers in recessive model (AA vs GG+GA) in PE group had significantly higher frequencies as compared to the controls $(\mathrm{p}=0.047, \mathrm{OR}=1.77,95 \% \mathrm{CI}=1.00-3.14)$. However, clinical variables in women with PE

Association of HLA-G 5'URR variants with

The association between 16 HLA-G 5'URR polymorphisms and clinical variables as the onset of PE, the highest systolic BP, the highest diastolic BP, serum creatinine, uric acid and total serum proteins level was performed in PE patients (Tab. 4). The analysis revealed that heterozygous $-533 \mathrm{delA}-/+$ carriers tended to have a significantly higher mean level of the highest diastolic BP as compared to other genotype carriers $(112.50 \pm 10.61 \mathrm{vs} 98.16 \pm 8.69$, $\mathrm{p}=0.02$ ). After adjustment for age and $+14 \mathrm{bp}$ Ins positivity, a statistically significant correlation between the above mentioned carriers and the higher mean level of the diastolic BP was also found $(p=0.003)$. Further findings revealed that after correction for age and $+14 \mathrm{bp}$ Ins positivity, a statistically significant association of -533 delA-/+ carriers with the higher mean level of the systolic BP was determined $(p=0.049)$ (Tab. 4).

Tab. 4. Association of HLA-G 5'URR polymorphisms with clinical signs of PE.

\begin{tabular}{|c|c|c|c|c|c|c|}
\hline \multirow{4}{*}{ Parameter } & \multicolumn{6}{|c|}{ HLA-G 5'URR genotypes } \\
\hline & \multicolumn{6}{|c|}{ Haploblock -762C/T, -716T/G, -689A/G, -666G/T, -633G/A } \\
\hline & $-762 \mathrm{CC}$ & $-762 \mathrm{CT}$ & $-762 \mathrm{TT}$ & $P / P^{*}$ & $P / P^{*}$ & $P / P^{*}$ \\
\hline & $(n=28)$ & $(n=53)$ & $(n=35)$ & $\mathrm{CM}$ & $\mathrm{DM}$ & $\mathrm{RM}$ \\
\hline Onset of PE, mean \pm SD (weeks) & $34.00 \pm 4.45$ & $34.67 \pm 4.23$ & $35.00 \pm 4.79$ & $0.77 / 0.74$ & $0.61 / 0.50$ & $0.50 / 0.59$ \\
\hline The highest systolic $\mathrm{BP}(\mathrm{mm} \mathrm{Hg})$, mean $\pm \mathrm{SD}$ & $150.39 \pm 17.37$ & $156.12 \pm 11.68$ & $153.72 \pm 19.51$ & $0.47 / 0.81$ & $0.92 / 0.59$ & $0.27 / 0.85$ \\
\hline The highest diastolic $\mathrm{BP}(\mathrm{mm} \mathrm{Hg})$, mean $\pm \mathrm{SD}$ & $98.89 \pm 10.53$ & $98.03 \pm 8.35$ & $98.96 \pm 8.91$ & $0.91 / 0.28$ & $0.77 / 0.88$ & $0.85 / 0.11$ \\
\hline Serum creatinine $(\mu \mathrm{mol} / 1)$, mean \pm SD & $61.11 \pm 13.56$ & $57.84 \pm 11.28$ & $60.63 \pm 14.69$ & $0.59 / 0.35$ & $0.59 / 0.51$ & $0.54 / 0.28$ \\
\hline Uric acid $(\mu \mathrm{mol} / 1)$, mean \pm SD & $323.65 \pm 82.65$ & $328.38 \pm 68.87$ & $298.40 \pm 71.60$ & $0.29 / 0.35$ & $0.12 / 0.15$ & $0.71 / 0.61$ \\
\hline \multirow[t]{3}{*}{ Total serum proteins $(\mathrm{g} / \mathrm{l})$, mean $\pm \mathrm{SD}$} & $57.63 \pm 6.57$ & $59.32 \pm 7.04$ & $59.16 \pm 5.99$ & $0.74 / 0.45$ & $0.84 / 0.64$ & $0.44 / 0.21$ \\
\hline & -533delA-/- & -533 delA-/+ & $-533 \mathrm{del} A+/+$ & $P / P^{*}$ & $P / P^{*}$ & $P / P^{*}$ \\
\hline & $(\mathrm{n}=114)$ & $(n=2)$ & $(\mathrm{n}=0)$ & $\mathrm{CM}$ & DM & RM \\
\hline Onset of PE, mean \pm SD (weeks) & $34.55 \pm 4.45$ & $37.50 \pm 0.71$ & $0.00 \pm 0.00$ & $0.35 / 0.22$ & - & - \\
\hline The highest systolic $\mathrm{BP}(\mathrm{mm} \mathrm{Hg})$, mean $\pm \mathrm{SD}$ & $153.55 \pm 15.77$ & $171.00 \pm 12.73$ & $0.00 \pm 0.00$ & $0.13 / \mathbf{0 . 0 4 9}$ & - & - \\
\hline The highest diastolic $\mathrm{BP}(\mathrm{mm} \mathrm{Hg})$, mean $\pm \mathrm{SD}$ & $98.16 \pm 8.69$ & $112.50 \pm 10.61$ & $0.00 \pm 0.00$ & $0.02 / 0.003$ & - & - \\
\hline Serum creatinine $(\mu \mathrm{mol} / 1)$, mean $\pm \mathrm{SD}$ & $59.12 \pm 12.75$ & $73.05 \pm 14.64$ & $0.00 \pm 0.00$ & $0.13 / 0.07$ & - & - \\
\hline Total serum proteins $(\mathrm{g} / \mathrm{l})$, mean $\pm \mathrm{SD}$ & $59.04 \pm 6.55$ & $54.17 \pm 6.61$ & $0.00 \pm 0.00$ & $0.31 / 0.28$ & - & - \\
\hline
\end{tabular}

$\mathrm{p}$ values were calculated using Student $\mathrm{t}$ test with Welch correction. $\mathrm{p}<0.05$ was considered as statistically significant, $\mathrm{p}^{*}-$ statistical analysis adjusted by age and $14 \mathrm{bp}$ insertion, $\mathrm{BP}$ - blood pressure, $\mathrm{n}$ - number, $\mathrm{CM}$ - co-dominant model, $\mathrm{DM}$ - dominant model, $\mathrm{RM}$ - recessive model, $\mathrm{SD}$ - standard deviation 


\section{Discussion}

Pre-eclampsia (PE) is one of the serious pregnancy-specific disease. Despite treatment, this multisystem disorder remains a major cause of maternal and neonatal mortality and morbidity worldwide. Biomarkers identifying the risk of PE were not available until now. According to clinical data, the potential markers of PE should relate to pathophysiology of the angiogenesis and inflammation $(5,6)$. Immunosuppressive molecule HLA-G belongs to candidate molecules with the potential to predict PE diagnosis. An important role of HLA-G in fetal development was described more than 20 years ago (7). The molecule is mainly expressed on cytotrophoblast cells of the placenta and induces the immune tolerance of fetus by maternal immune response $(7,9)$. It is accepted that expression of HLA-G may be influenced by the polymorphic variants in the 5' and 3' untranslated regions. In the 3'UTR region, a 14 bp insertion polymorphism (5'- ATTTGTTCATGCCT-3'), which affects the stability of mRNA has been mostly analyzed (14). However, the meta-analyses of several smaller studies revealed no associations between the HLAG 14bp Ins/Del genotype and the development of PE $(28,36)$. The other polymorphisms in the 3'UTR that can influence soluble HLA-G level including SNPs at the $+3142(\mathrm{C} / \mathrm{G}),+3187(\mathrm{~A} / \mathrm{G})$ and +3196 position $(\mathrm{C} / \mathrm{G})$. They can target certain miRNAs that are responsible for degrading HLA-G mRNA $(+3142 \mathrm{C} / \mathrm{G})$ or are located just before and after an AUUUA motif associated with mRNA stability $(+3187 \mathrm{~A} / \mathrm{G}$, $+3196 \mathrm{C} / \mathrm{G}$ ) (37). Polymorphisms in the HLA-G 5'URR region, i.e. in the promoter can also affect the regulation of gene expression $(15,38)$. However, there is no consensus, which HLA-G variants predispose to complications of pregnancy, such as recurrent miscarriages or pre-eclampsia.

In our study, we compared the allelic and genotypic frequencies of 16 HLA-G 5'URR polymorphisms (from -762 to - 201bp) between the women suffering from PE and the controls. HLA-G 5'URR region (promoter) consists of the $1.4 \mathrm{~kb}$ upstream the ATG and includes several enhancer and suppressors elements to regulate HLA-G expression (16-18). Only few studies reported the association of HLA-G 5'URR region with a susceptibility to recurrent miscarriages to date (39-43). Ober et al (39) reported the highest fetal loss rates among couples, who carried $-725 \mathrm{G}$ allele. Berger et al (40) found a significant association between -486A/C SNP and miscarriage. Agrawal and colleagues (42) reported the association of women carriers with mutant genotypes of $-1179 \mathrm{G} / \mathrm{A}$, $-725 \mathrm{C} / \mathrm{G} / \mathrm{T}$ and $-486 \mathrm{~A} / \mathrm{C}$ with an increased risk of developing recurrent spontaneous abortion (RSA). They also have seen a decreased mRNA HLA-G expression for -1179AA and -725GG genotypes in cases of idiopathic RSA. Yazdani et al (43) found the impact of $-1573 \mathrm{~T} / \mathrm{C}$ and $-1746 \mathrm{C} / \mathrm{A}$ SNPs in the promoter of the HLA-G gene on the risk to recurrent pregnancy loss. However, no study evaluated an association of HLA-G 5'URR region with a susceptibility to develop PE until now. Our results revealed that -201AA genotypes in a recessive model were significantly more frequent in women with pre-eclampsia than in the controls. As it is known that $-201 \mathrm{G} / \mathrm{A}$ polymorphism is located in the NF- $\chi \mathrm{B} 2$ element (enhancer A), its possible involvement in affecting gene expression can be hypothesized (38). It can be speculated that the minor allele at positions -201 may affect the binding of transcription factor leading to differences in HLA-G expression.

The distribution of the HLA-G 5'URR haplotypes including $14 \mathrm{bp}$ polymorphism at the $3^{\prime} \mathrm{UTR}$ in women with PE and the control group was also performed. The HLA-G 5'URR-1 was the most frequent haplotype in women with PE, and HLA-G 5'URR-2 was the most frequent in the control group. No statistically significant differences in haplotype frequencies between PE patients and the controls were observed. Hviid et al (44) reported that the HLAG 5'URR-1 (composed by -762T, -725C, -716G, -689G, -666T, $-646 \mathrm{~A},-633 \mathrm{~A},-509 \mathrm{C},-486 \mathrm{C},-477 \mathrm{G},-400 \mathrm{G},-391 \mathrm{G},-369 \mathrm{~A},-201 \mathrm{~A}$, $14 \mathrm{bp}$ Ins) is the most frequent haplotype in human population.

In our study, the association between HLA-G 5'URR variants and the main clinical variables such as the onset of PE, the highest systolic BP, the highest diastolic BP, serum creatinine, uric acid and total serum proteins level was also evaluated. To our knowledge, such correlation analysis in PE cases wasn't reported until now. Our results revealed that heterozygous $-533 \mathrm{delA}-/+$ carriers tend to have the higher mean level of the highest diastolic BP as compared to other genotype carriers. After adjustment for age and +14bp Ins positivity, a statistically significant correlation between the above mentioned carriers and the higher mean level of the diastolic BP was also found. Endothelial dysfunction is the one of the main causes involved in the pathophysiology of PE (45). The impairment of the vascular endothelium leads to a disturbed balance between vasoconstrictive and vasodilatation substances. It was shown that sHLA-G inhibits endothelial cell proliferation, providing an evidence that HLA-G may play an essential role in vascular remodeling (46). It should be hypothesized that a decreased level of HLA-G resulting from-533delA-/+ polymorphism is one of the mechanisms to cause endothelial dysfunction leading to hypertension in PE patients.

Many studies showed that the decreased HLA-G level is associated with complications of pregnancy including pre-eclampsia (19-23, 47-49). Some studies reported the impact of HLA-G 5'URR polymorphisms on HLA-G expression. Higher HLA-G transcription rate in JEG-3 choriocarcinoma cell was described for the miscarriage-associated HLA-G -725G allele (50). It is in accordance with study of Jassem et al (41), who reported lower levels of sHLA-G in RPL women carriers for -725CC genotypes. Among other SNPs at 5'URR, the -716TT and -201GG genotypes have been associated with high soluble HLA-G levels (51). Concerning our results, the -201AA genotypes should be associated with a decreased HLA-G expression causing an impaired HLA-G function during pregnancy. Taken together, our observations suggest that HLA-G 5'URR variants may create an immunological microenvironment, which may affect the fetal-maternal tolerance. HLA-G gene variants seem to be promising biomarkers to further investigate their role in pathogenesis of PE.

\section{Learning points}

- This is the first study performing a comprehensive association analysis between 16 HLA-G 5'URR variants (promoter) and the risk of developing pre-eclampsia in Slovak women. 
- The -201AA genotypes in recessive model were significantly more frequent in women with pre-eclampsia than in the controls.

- The -533delA-/+ women carriers tend to have a significantly higher mean level of the diastolic blood pressure as compared to other genotype carriers.

- Our results suggest that HLA-G 5'URR variants may create an immunological microenvironment, which could affect the fetal-maternal tolerance.

\section{References}

1. Steegers EA, von Dadelszen P, Duvekot JJ, Pijnenborg R. Pre-eclampsia. Lancet 2010; 376 (9741): 631-644.

2. Redman CW, Sargent IL. Latest advances in understanding preeclampsia. Science 2005; 308 (5728): 1592-1594.

3. Steinberg G, Khankin EV, Karumanchi SA. Angiogenic factors and preeclampsia. Thromb Res 2009; 123 Suppl 2S93-99.

4. Gyselaers W. Preeclampsia Is a Syndrome with a Cascade of Pathophysiologic Events. Journal of clinical medicine 2020; 9 (7).

5. He A, Zhou Y, Wei Y, Li R. Potential Protein Biomarkers for Preeclampsia. Cureus 2020; 12 (6): e8925.

6. Mohamad MA, Mohd Manzor NF, Zulkifli NF, Zainal N, Hayati AR, Ahmad Asnawi AW. A Review of Candidate Genes and Pathways in Preeclampsia-An Integrated Bioinformatical Analysis. Biology 2020; 9 (4).

7. Kovats S, Main EK, Librach C, Stubblebine M, Fisher SJ, DeMars R. A class I antigen, HLA-G, expressed in human trophoblasts. Science 1990; 248 (4952): 220-223.

8. Geraghty DE, Koller BH, Orr HT. A human major histocompatibility complex class I gene that encodes a protein with a shortened cytoplasmic segment. Proc Natl Acad Sci U S A 1987; 84 (24): 9145-9149.

9. Gonzalez A, Rebmann V, LeMaoult J, Horn PA, Carosella ED, Alegre E. The immunosuppressive molecule HLA-G and its clinical implications. Crit Rev Clin Lab Sci 2012; 49 (3): 63-84.

10. LeMaoult J, Zafaranloo K, Le Danff C, Carosella ED. HLA-G upregulates ILT2, ILT3, ILT4, and KIR2DL4 in antigen presenting cells, NK cells, and T cells. FASEB J 2005; 19 (6): 662-664.

11. LeMaoult J, Caumartin J, Daouya $\mathbf{M}$ et al. Immune regulation by pretenders: cell-to-cell transfers of HLA-G make effector T cells act as regulatory cells. Blood 2007; 109 (5): 2040-2048.

12. Puppo F, Contini P, Ghio M, Indiveri F. Soluble HLA class I molecules/CD8 ligation trigger apoptosis of CD8+ cells by Fas/Fas-ligand interaction. ScientificWorldJournal 2002; 2421-423.

13. Le Bouteiller P, Solier C, Proll J, Aguerre-Girr M, Fournel S, Lenfant F. Placental HLA-G protein expression in vivo: where and what for? Hum Reprod Update 1999; 5 (3): 223-233.

14. Rousseau P, Le Discorde M, Mouillot G, Marcou C, Carosella ED, Moreau P. The 14 bp deletion-insertion polymorphism in the 3' UT region of the HLA-G gene influences HLA-G mRNA stability. Hum Immunol 2003; 64 (11): 1005-1010.

15. Dias FC, Bertol BC, Poras I et al. The genetic diversity within the 1.4 kb HLA-G 5' upstream regulatory region moderately impacts on cellular microenvironment responses. Sci Rep 2018; 8 (1): 5652.

16. Yie SM, Xiao R, Librach CL. Progesterone regulates HLA-G gene expression through a novel progesterone response element. Hum Reprod 2006; 21 (10): 2538-2544.
17. Moreau P, Flajollet S, Carosella ED. Non-classical transcriptional regulation of HLA-G: an update. J Cell Mol Med 2009; 13 (9B): 2973-2989.

18. Flajollet S, Poras I, Carosella ED, Moreau P. RREB-1 is a transcriptional repressor of HLA-G. J Immunol 2009; 183 (11): 6948-6959.

19. Yie SM, Taylor RN, Librach C. Low plasma HLA-G protein concentrations in early gestation indicate the development of preeclampsia later in pregnancy. Am J Obstet Gynecol 2005; 193 (1): 204-208.

20. Steinborn A, Varkonyi T, Scharf A, Bahlmann F, Klee A, Sohn C. Early detection of decreased soluble HLA-G levels in the maternal circulation predicts the occurrence of preeclampsia and intrauterine growth retardation during further course of pregnancy. Am J Reprod Immunol 2007; 57 (4): 277-286.

21. Darmochwal-Kolarz D, Kolarz B, Rolinski J, Leszczynska-Gorzelak B, Oleszczuk J. The concentrations of soluble HLA-G protein are elevated during mid-gestation and decreased in pre-eclampsia. Folia Histochem Cytobiol 2012; 50 (2): 286-291.

22. He Y, Chen S, Huang H, Chen Q. Association between decreased plasma levels of soluble human leukocyte antigen-G and severe pre-eclampsia. J Perinat Med 2016; 44 (3): 283-290.

23. Rokhafrooz S, Ghadiri A, Ghandil $\mathbf{P}$ et al. Association between HLA-G 14bp Gene Polymorphism and Serum sHLA-G Protein Concentrations in Preeclamptic Patients and Normal Pregnant Women. Immunol Invest 2018; 47 (6): 558-568.

24. Hylenius S, Andersen AM, Melbye M, Hviid TV. Association between HLA-G genotype and risk of pre-eclampsia: a case-control study using family triads. Mol Hum Reprod 2004; 10 (4): 237-246.

25. Vianna P, Dalmáz CA, Veit TD, Tedoldi C, Roisenberg I, Chies JA. Immunogenetics of pregnancy: role of a 14-bp deletion in the maternal HLA-G gene in primiparous pre-eclamptic Brazilian women. Hum Immunol 2007; 68 (8): 668-674.

26. Iversen AC, Nguyen OT, Tommerdal LF et al. The HLA-G 14bp gene polymorphism and decidual HLA-G 14bp gene expression in pre-eclamptic and normal pregnancies. J Reprod Immunol 2008; 78 (2): 158-165.

27. Zhang Z, Li Y, Zhang LL, Jia LT, Yang XQ. Association of 14 bp insertion/deletion polymorphism of the HLA-G gene in father with severe preeclampsia in Chinese. Tissue Antigens 2012; 80 (2): 158-164.

28. Pabalan N, Jarjanazi H, Sun C, Iversen AC. Meta-analysis of the human leukocyte antigen-G (HLA-G) 14 bp insertion/deletion polymorphism as a risk factor for preeclampsia. Tissue Antigens 2015; 86 (3): 186-194.

29. Mando C, Pileri P, Mazzocco MI et al. Maternal and fetal HLA-G 14 bp gene polymorphism in pregnancy-induced hypertension, preeclampsia, intrauterine growth restricted and normal pregnancies. J Matern Fetal Neonatal Med 2016; 29 (9): 1509-1514.

30. Durmanova V, Drobny J, Shawkatova I, Dlhopolcek J, Bucova M. Analysis of HLA-G gene polymorphisms in Slovak women with preeclampsia. Bratislava Medical Journal 2017; 118 (9): 517-522.

31. Ferreira LC, Lopes TPB, Guimaraes TB, Gomes CEM, Jeronimo SMB. The maternal 14 bp Ins/Del polymorphism in HLA-G is not associated with preeclampsia risk. Int J Immunogenet 2017; 44 (6): 350-355.

32. Lindheimer MD, Taler SJ, Cunningham FG. Hypertension in pregnancy. J Am Soc Hypertens 2010; 4 (2): 68-78.

33. Miller SA, Dykes DD, Polesky HF. A simple salting out procedure for extracting DNA from human nucleated cells. Nucleic Acids Res 1988; $16(3): 1215$. 


\section{3-860}

34. Catamo E, Addobbati C, Segat $\mathrm{L}$ et al. Comprehensive analysis of polymorphisms in the HLA-G 5' upstream regulatory and 3' untranslated regions in Brazilian patients with systemic lupus erythematosus. Tissue Antigens 2015; 85 (6): 458-465.

35. Stephens M, Smith NJ, Donnelly P. A new statistical method for haplotype reconstruction from population data. Am J Hum Genet 2001; 68 (4): 978-989.

36. de Almeida BS, Muniz YCN, Prompt AH, Castelli EC, MendesJunior CT, Donadi EA. Genetic association between HLA-G 14-bp polymorphism and diseases: A systematic review and meta-analysis. Hum Immunol 2018; 79 (10): 724-735.

37. Castelli EC, Mendes-Junior CT, Deghaide NH et al. The genetic structure of 3'untranslated region of the HLA-G gene: polymorphisms and haplotypes. Genes Immun 2010; 11 (2): 134-141.

38. Castelli EC, Veiga-Castelli LC, Yaghi L, Moreau P, Donadi EA. Transcriptional and posttranscriptional regulations of the HLA-G gene. J Immunol Res 2014; 2014734068.

39. Ober C, Aldrich CL, Chervoneva I et al. Variation in the HLA-G promoter region influences miscarriage rates. Am J Hum Genet 2003; 72 (6): 1425-1435.

40. Berger DS, Hogge WA, Barmada MM, Ferrell RE. Comprehensive analysis of HLA-G: implications for recurrent spontaneous abortion. Reprod Sci 2010; 17 (4): 331-338.

41. Jassem RM, Shani WS, Loisel DA, Sharief M, Billstrand C, Ober C. HLA-G polymorphisms and soluble HLA-G protein levels in women with recurrent pregnancy loss from Basrah province in Iraq. Hum Immunol 2012; 73 (8): 811-817.

42. Agrawal D, Prakash S, Misra MK, Phadke SR, Agrawal S. Implication of HLA-G 5' upstream regulatory region polymorphisms in idiopathic recurrent spontaneous abortions. Reprod Biomed Online 2015; 30 (1): 82-91.
43. Yazdani N, Shekari Khaniani M, Bastami M, Ghasemnejad T, Afkhami F, Mansoori Derakhshan S. HLA-G regulatory variants and haplotypes with susceptibility to recurrent pregnancy loss. Int J Immunogenet 2018; 45 (4): 181-189.

44. Hviid TV, Rizzo R, Melchiorri L, Stignani M, Baricordi OR. Polymorphism in the 5 ' upstream regulatory and 3 ' untranslated regions of the HLA-G gene in relation to soluble HLA-G and IL-10 expression. Hum Immunol 2006; 67 (1-2): 53-62.

45. Myatt L, Webster RP. Vascular biology of preeclampsia. Journal of thrombosis and haemostasis : JTH 2009; 7 (3): 375-384.

46. Fons P, Chabot S, Cartwright JE et al. Soluble HLA-G1 inhibits angiogenesis through an apoptotic pathway and by direct binding to CD160 receptor expressed by endothelial cells. Blood 2006; 108 (8): 2608-2615.

47. Steinborn A, Rebmann V, Scharf A, Sohn C, Grosse-Wilde H. Placental abruption is associated with decreased maternal plasma levels of soluble HLA-G. J Clin Immunol 2003; 23 (4): 307-314.

48. Hackmon R, Koifman A, Hyodo H, Glickman H, Sheiner E, Geraghty DE. Reduced third-trimester levels of soluble human leukocyte antigen G protein in severe preeclampsia. Am J Obstet Gynecol 2007; 197 (3): 255 e251-255.

49. Rizzo R, Andersen AS, Lassen MR et al. Soluble human leukocyte antigen-G isoforms in maternal plasma in early and late pregnancy. Am J Reprod Immunol 2009; 62 (5): 320-338.

50. Ober C, Billstrand C, Kuldanek S, Tan Z. The miscarriage-associated HLA-G -725G allele influences transcription rates in JEG-3 cells. Hum Reprod 2006; 21 (7): 1743-1748.

51. Carlini F, Traore K, Cherouat N et al. HLA-G UTR haplotype conservation in the Malian population: association with soluble HLA-G. PLoS One 2013; 8 (12): e82517. 